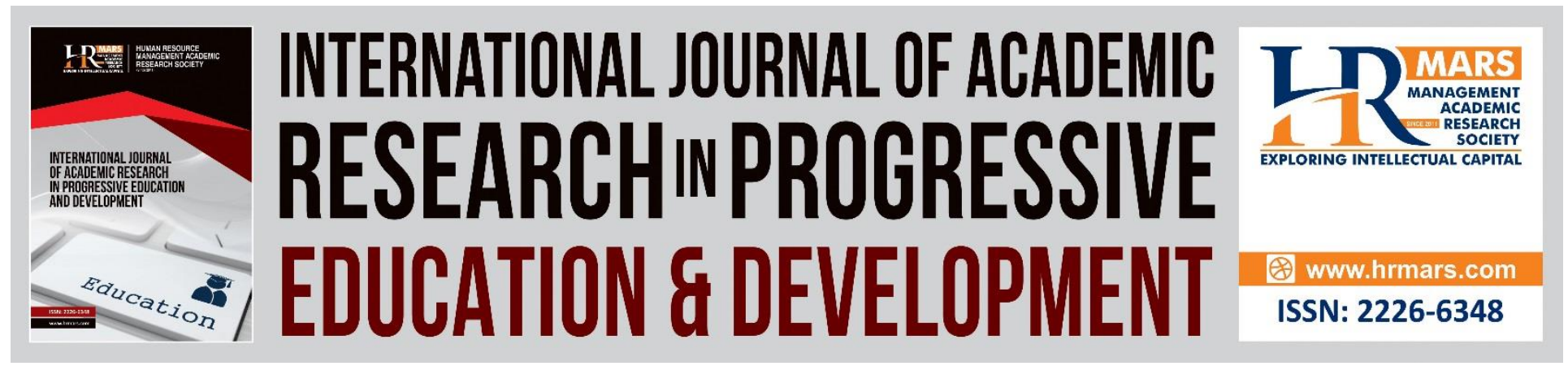

\title{
School Teachers' Strategic Thinking Skills: Cross-Sectional Survey Based on Demographic Factors
}

\section{Mua'azam Mohamad \& Hishamudin Mohamad Twontawi}

To Link this Article: http://dx.doi.org/10.6007/IJARPED/v10-i2/10134

DOI:10.6007/IJARPED/v10-i2/10134

Received: 01 April 2021, Revised: 13 May 2021, Accepted: 27 May 2021

Published Online: 12 June 2021

In-Text Citation: (Mohamad \& Twontawi, 2021)

To Cite this Article: Mohamad, M., \& Twontawi, H. M. (2021). School Teachers' Strategic Thinking Skills: CrossSectional Survey Based on Demographic Factors. International Journal of Academic Research in Progressive

Education and Development, 10(2), 530-541.

Copyright: (C) 2021 The Author(s)

Published by Human Resource Management Academic Research Society (www.hrmars.com)

This article is published under the Creative Commons Attribution (CC BY 4.0) license. Anyone may reproduce, distribute, translate and create derivative works of this article (for both commercial and non-commercial purposes), subject to full attribution to the original publication and authors. The full terms of this license may be seen at: http://creativecommons.org/licences/by/4.0/legalcode

Vol. $10(2)$ 2021, Pg. 530 - 541

http://hrmars.com/index.php/pages/detail/IJARPED

JOURNAL HOMEPAGE

Full Terms \& Conditions of access and use can be found at http://hrmars.com/index.php/pages/detail/publication-ethics 


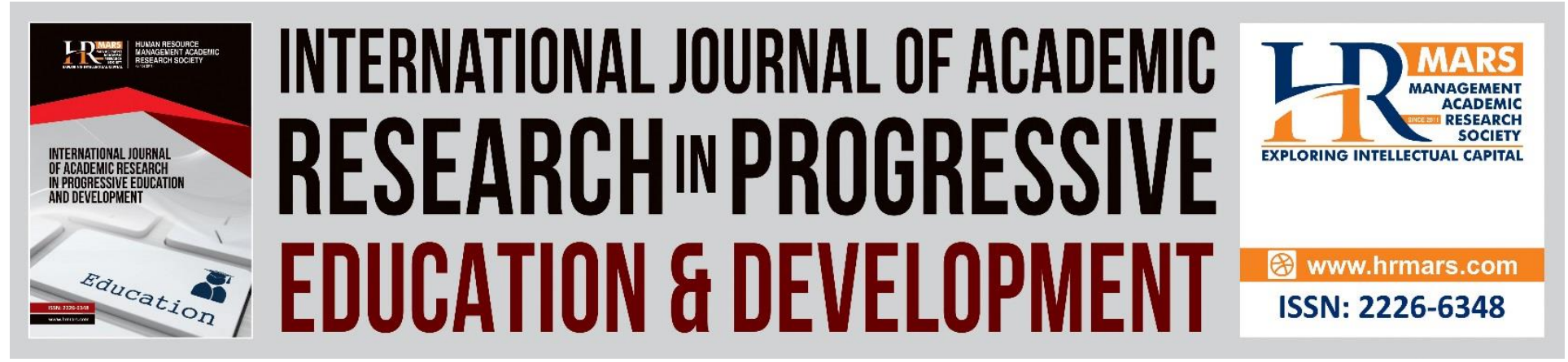

\title{
School Teachers' Strategic Thinking Skills: Cross- Sectional Survey Based on Demographic Factors
}

\author{
Mua'azam Mohamad \& Hishamudin Mohamad Twontawi \\ School of Education Universiti Utara Malaysia.
}

\begin{abstract}
Education reform programs are implemented as a platform to improve the quality of the education system through continuous quality improvement practices. This study aimed to examine the level of strategic thinking skills and its differences based on demographic (school category) aspects. The cross-sectional survey method was applied in the data collection process. The research instrument used was the Strategic Thinking Skills questionnaire. A total of 456 respondents were selected using the stratified random sampling method in this study. The results showed that the schoolteachers' strategic thinking skills were at a relatively high level. There were statistically significant differences in strategic thinking skills in terms of respondents' positions and academic qualifications. On the other hand, there were no significant differences in the factors of school category, gender, age and teaching qualification. The findings of this study proved that strategic thinking skills have been practiced among school teachers despite varying aspects of implementation. As such, it should be given due consideration by the stakeholders at the school management level to increase the mastery of strategic thinking skills towards improving teacher professionalism and school improvement.
\end{abstract}

Keywords: Strategic Thinking Skills, Schoolteachers, Secondary School, Primary School, Quality of Education.

\section{Introduction}

The implementation of the Malaysian Education Development Plan (PPPM) (2013-2025) sets the goals and aspirations towards upholding a quality education system in Malaysia. A combined effort in the second wave of implementation is hoped to be achieved effectively through the cooperation of all parties, especially the commitment of educators in schools (Abdul Razak, 2012). In line with the desire to improve the quality of the education system in general, and the excellence of the school in particular, the national education system has focused leadership on every member of the educational institution (Kementerian Pendidikan Malaysia, 2013). The objectives of the PPPM (2013 - 2025) include school leadership that will be extended to teachers who hold leadership positions in schools. This means that, in addition to principals, school leadership can also be contributed by senior assistant teachers or regular teachers (KPM, 2013). 
According to Caldwell and Spinks (1988), educational organizations should have strong management and be able to develop strategies that include aspects of analyzing the external environment, human leadership, structure, technology, politics, culture and education.

Effective leadership strategies must be present at all levels of leadership in schools (Kowalski, 2010). Based on the literature review, scholars have found that teachers' strategic approach can have an impact on students' academic achievement in schools (Ali, 2012). This demands that school teachers hone their strategic skills to enhance school leadership capabilities. In fact, Pisapia (2009) accentuates that the fundamental tenet of strategic orientation skills is the ability of individuals to develop strategic thinking skills that enhance their level of mastery of strategy. The mastery of strategic thinking can help to devise more effective task strategies (Mintzberg, 2000). In this regard, school teachers are required to develop strong leadership skills and to be able to master strategic skills to formulate effective school improvement strategies. (Davies, 2004; Fullan, 2007).

In contrast, Beatty (2010) found that less than $10 \%$ of leaders exhibit strategic skills in organizations. In addition, Atan (2013) found that teachers carry a relatively high burden of responsibility in implementing school improvement strategy agendas that will indirectly impact self-motivation and teachers' ability to translate school mindset (Sihes \& Shaari, 2010). In fact, Fullan (2007) has identified a group of school leaders as strategic planners in the school community who are difficult to plan and implement strategic planning effectively. In this regard, Dom (2006) emphasized the need for strategic planning at the school level to apply strategic skills and achieve the goals and objectives of improving the quality of education. Thus in implementing the educational development agenda, aspects of strategic skills and teacher leadership should be the focus of discussion and research in the implementation of education system quality improvement strategies (Ali, 2012). Based on the literature review, there is a significant shortage of such studies especially in the education sector in developing countries such as Malaysia. Therefore, the findings of this study can serve as a platform to provide important additional information to the body of knowledge about the level of strategic skill being studied as compared to the results of the same study. In addition, this study also has several interests that can be utilized by certain parties in optimizing the understanding of the role of strategic thinking skills in enhancing leadership ability and motivation among school teachers in the country.

\section{Strategic Thinking Skills}

The term strategic thinking skills refer to the skills of individuals who practice thinking activities to benefit the organization. These skills are cultivated to provide a detailed competitive strategy towards achieving organizational goals. According to Haycock et al. (2012) strategic thinking activities can contribute to the broader concept of planning and focus on the future direction of the organization in order to continue operating in line with current situation. In addition, strategic thinking activities are also an integral part of strategic planning in organizational management to identify and plan new innovations to as to sustain and stay relevant in the industry. Strategic thinking can be defined as an individual thinking for the purpose of designing a competitive strategy within an organization (Haycock et al., 2012). Whereas Weyhrauch (2016) argues that through strategic thinking processes which are synthetic, high creativity, innovative, diverse and intuitive, it is possible to realize strategic planning developed in accordance with the 
organization. In fact, based on a literature review, strategic thinking skills have a broad meaning. A popular pioneer in the development of strategic planning theory is Mintzhberg (2000) who argues that strategy is an art in which strategy must be practiced primarily as an intuitive, creative and unique thinking process.

Heracleous (1998) defines strategic thinking as a management activity aimed at discovering novel, imaginative strategies that can reproduce competitive games and anticipate significantly different potentials from current situations. On the contrary, strategic thinking has no clear meaning and is often debated with strategic planning (Heracleous, 1998). However, Jelenc and Pisapia (2015) concluded that strategic thinking is an activity that influences an individual's proactive behavior in an organization to achieve their vision and mission. In this regard, if the strategic thinking level is high, the tendency for the members of the organization to think creatively, proactively, work hard, show persistence and persistence and exhibit high collaborative behavior will also be at a high level, which in overall make the implementation of the planned strategy becomes more effective.

Discussing this complex aspect, Kalhori and Shahhoseini (2015) proposed a number of factors that influences the formation of strategic thinking whereby firstly, every employee needs to be trained in technical knowledge and management in preparation for problem solving. Second, a comprehensive source of training for new staff is organized to create awareness of opportunities. Third, management should eliminate barriers to organizational structure and practice more flexible regulation to encourage more positive creative and innovative thinking. Fourth, focus on the goal of coordinating and working with staff through innovation challenges, identifying opportunities and reducing barriers to change. Fifth, be transparent in the issue of continuing education and learning through seminars, conferences and workshops.

This research focused on three main dimensions using the strategic thinking theory introduced by Pisapia (2009), namely systems thinking, reflection and reframing. The systems thinking refers to a leader's ability to view the system holistically by understanding the nature, power, pattern and relationship that shape the behavior of the system that provides the options for actions. Meanwhile reflection is a leader's ability to think logically and rationally through perceptions, experiences and information to evaluate what has happened and to form an intuitive principle as a guide to future actions. Reframing refers to a leader's ability to draw attention through a variety of perspectives, frameworks, models of thought, and paradigms to build new insights and choices for action. These three dimensions are key factors that shape strategic thinking.

\section{Research Objectives}

The purpose of this study was to identify the descriptive picture of strategic thinking skills among various groups of school teachers in Malaysia. It is hoped that a better understanding of the characteristics and practices of thinking skills will help enhance the focus and effectiveness of future teacher engagement and policy initiatives. Based on the literature review, the objectives of this study were to: examine the level of strategic thinking skills among school teachers and identify the most commonly used aspects of thinking. This study also examined the differences in the level of strategic thinking skills among school teachers based on demographic factors. This information, we hope, will be a good starting point for guiding future research and intervention 
programs aimed at addressing the specific needs of diverse groups in this diverse teacher population.

\section{Research Methodology \\ Population and Sampling}

The target population consisted of all teachers teaching at the national secondary (SMK) and national primary (SK) schools totaling of 104 schools under the administration of the Perlis State Education Department. The survey instrument was distributed to 500 teachers in 20 SMKs and 20 SKs and out of this, a total of 484 respondents returned the questionnaire. However, after filtering only 456 questionnaires were completed for analysis and were analyzed according to various demographic characteristics. A total of 219 (48.0\%) respondents represented the secondary school while 237 (52.0\%) respondents represented the primary school category aging from 25 to 60 years. The distribution of respondents based on school location indicated that urban schools dominated the category of school location. A total of 255 respondents (55.9\%) were teaching in urban schools while 201 respondents (44.1\%) in rural schools. Meanwhile, from the distribution in terms of gender it was found that the number of female respondents which was $351(77.0 \%)$ surpassed the number of male respondents which was 105 (23.0\%).

Table 1. Profile of Respondents Based on Demographic Features Distribution $(n=456)$

\begin{tabular}{|c|c|c|c|}
\hline & Demographic Features & Frequency & Percentage \\
\hline \multicolumn{4}{|l|}{ 1. School Category } \\
\hline & Secondary School (SMK) & 219 & 48.0 \\
\hline & Primary School (SK) & 237 & 52.0 \\
\hline \multicolumn{4}{|l|}{ 2. Gender } \\
\hline & Male & 105 & 23.0 \\
\hline & Female & 351 & 77.0 \\
\hline \multicolumn{4}{|l|}{ 3. Age } \\
\hline & $20-29$ years old & 21 & 4.6 \\
\hline & $30-39$ years old & 147 & 32.2 \\
\hline & $40-49$ years old & 180 & 39.5 \\
\hline & 50 years and above & 108 & 23.7 \\
\hline \multicolumn{4}{|l|}{ 4. Teaching Experience } \\
\hline & 1 - 10 years & 98 & 21.5 \\
\hline & 11 - 20 years & 148 & 32.5 \\
\hline & 21 - 30 years & 185 & 40.6 \\
\hline & More than 30 years & 25 & 5.5 \\
\hline \multicolumn{4}{|l|}{ 5. Academic Qualification } \\
\hline & Doctorate & 1 & 0.2 \\
\hline & Master & 58 & 12.7 \\
\hline & Bachelor & 331 & 72.6 \\
\hline & Dip/Cert/STPM/STAM & 49 & 10.7 \\
\hline & SPM & 17 & 3.7 \\
\hline 6. Teaching Qualification & & & \\
\hline
\end{tabular}


7. Position

$\begin{array}{lrr}\text { BED Teaching College } & 25 & 5.5 \\ \text { BED Public University } & 69 & 15.1 \\ \text { DIP ED Teaching College } & 280 & 61.4 \\ \text { DIP ED Public University } & 82 & 18.0\end{array}$

$\begin{array}{lrr}\text { Senior Assistant } & 29 & 6.4 \\ \text { Head of Field } & 34 & 7.5 \\ \text { Class Teacher } & 125 & 27.4 \\ \text { Head of Subject } & 90 & 19.7 \\ \text { Secretary } & 29 & 6.4 \\ \text { Regular Teacher } & 149 & 32.7\end{array}$

\section{Research Instrument}

The research instrument used to measure the level of strategic thinking skills was adapted from the Strategic Thinking Questionnaire (Pisapia et al., 2011) which was divided into three categories namely reframing, reflection and systems thinking. The questionnaire consisted of 18 items that were rated on a 7-point Likert scale to increase reliability and reduce errors during data collection (Vagias, 2006).

Table 2. Psychometric Properties of the Strategic Thinking Questionnaire

\begin{tabular}{lrrrrr}
\hline Item & Mean & $\begin{array}{r}\text { Standard } \\
\text { Deviation }\end{array}$ & $\begin{array}{c}\text { Scale Variance if } \\
\text { Item Deleted }\end{array}$ & $\begin{array}{c}\text { Corrected Item- } \\
\text { Total Correlation }\end{array}$ & $\begin{array}{c}\text { Cronbach's Alpha if } \\
\text { Item Deleted }\end{array}$ \\
\hline ST1 & 4.53 & 1.095 & 86.741 & .468 & .820 \\
ST2 & 4.70 & 1.048 & 89.764 & .333 & .827 \\
ST3 & 4.91 & 1.051 & 85.438 & .563 & .815 \\
ST4 & 4.97 & .958 & 87.082 & .530 & .817 \\
ST5 & 4.06 & 1.161 & 87.315 & .406 & .823 \\
ST6 & 4.76 & .969 & 85.670 & .606 & .814 \\
ST7 & 5.07 & .976 & 86.568 & .548 & .816 \\
ST8 & 4.97 & .955 & 85.912 & .602 & .814 \\
ST9 & 4.76 & .914 & 86.158 & .618 & .814 \\
ST10 & 4.81 & .957 & 85.866 & .603 & .814 \\
ST11 & 4.73 & 1.010 & 86.280 & .542 & .816 \\
ST12 & 4.79 & .936 & 86.325 & .591 & .815 \\
ST13 & 4.58 & 1.002 & 85.545 & .589 & .814 \\
ST14 & 3.86 & 1.322 & 93.211 & .099 & .843 \\
ST15 & 3.87 & 1.312 & 93.293 & .097 & .843 \\
ST16 & 4.04 & 1.300 & 91.281 & .181 & .838 \\
ST17 & 4.27 & 1.212 & 88.782 & .316 & .829 \\
ST18 & 4.58 & 1.123 & 89.412 & .321 & .828 \\
Cronbach's Alpha & .831 & & & & \\
\hline
\end{tabular}


Vol. 10, No. 2, 2021, E-ISSN: 2226-6348 @ 2021 HRMARS

Based on the analysis of the research data, the 'alpha cronbach' value of all strategic thinking skills items showed high value (0.831). This indicates that all items in the questionnaire have internal reliability that was categorized as excellent. Most researchers suggest that alpha coefficients above 0.8 typically indicate a high level of reliability (Anastasi \& Urbina, 1997; Cohen, Manion \& Morrison, 2011; Sekaran \& Bougie, 2010).

\section{Research Findings and Discussion \\ Strategic Thinking Skills}

Descriptive analysis (mean and standard deviation) was used to describe the level of strategic thinking skills based on the categories of schools in the list of selected schools. The overall mean value for each dimension of strategic thinking skills was then compared to the mean value based on the mean classification to determine whether the level of strategic leadership practice was high or low according to the category of department as shown in Table 3 below.

Table 3. Strategic Thinking Skills Levels by School Category

\begin{tabular}{lcccccc}
\hline Variables & Overall $(\mathbf{n = 4 5 6 )}$ & \multicolumn{2}{c}{$\begin{array}{c}\text { Secondary School } \\
\text { Category SMK } \\
(\mathbf{n = 2 1 9 )}\end{array}$} & \multicolumn{2}{c}{$\begin{array}{c}\text { Primary School } \\
\text { Category } \\
\text { SK (n=237) }\end{array}$} \\
\cline { 2 - 7 } & Mean & SD & Mean & SD & Mean & SD \\
\hline Strategic Thinking Skills & 4.57 & .55 & 4.58 & .57 & 4.56 & .53 \\
Reflection & 4.63 & .74 & 4.68 & .78 & 4.59 & .69 \\
Systems Thinking & 4.81 & .72 & 4.84 & .74 & 4.78 & .69 \\
Reframing & 4.13 & .79 & 4.08 & .84 & 4.17 & .73 \\
\hline
\end{tabular}

Based on Table 3 above, the findings indicated that the level of strategic thinking skills among school teachers as a whole was relatively high. $(M=4.57, S D=0.55)$. When examined in detail in Table 3, the results of the data analysis revealed that the level of strategic thinking skills of the SMK school teachers was higher than that of the SK school teachers. Further analysis of the strategic leadership dimension, it was found that overall the dimension of systems thinking had the highest mean value $(M=4.81)$ followed by the reflection dimension $(M=4.63)$ and the reframing dimension $(M=4.13)$.

\section{Differences in Strategic Thinking Skill Level}

School Category. Overall the independent sample t-test result in Table 4 showed that there were no statistically significant differences in terms of strategic thinking skills based on school category variables $(t=0.43, p>0.05)$. In addition, univariate analysis of the dimensions of strategic thinking skills also showed that there were no significant differences in the dimensions of strategic thinking skills based on school categories in the dimensions for reflection $(t=1.21, p>0.05)$, systems thinking $(t=0.82, p>0.05)$ and reframing $(t=-1.26, p>0.05)$. 
INTERNATIONAL JOURNAL OF ACADEMIC RESEARCH IN PROGRESSIVE EDUCATION AND

DEVELOPMENT

Vol. 10, No. 2, 2021, E-ISSN: 2226-6348 @ 2021 HRMARS

Table 4. t-Test: Strategic Thinking Differences Based on School Category

\begin{tabular}{|c|c|c|c|c|c|c|}
\hline \multirow[t]{2}{*}{ Variables } & \multicolumn{2}{|c|}{$\begin{array}{c}\text { Secondary } \\
\text { School Category } \\
(n=219)\end{array}$} & \multicolumn{2}{|c|}{$\begin{array}{l}\text { Primary School } \\
\text { Category }(n=237)\end{array}$} & \multirow[t]{2}{*}{ t Value } & \multirow[t]{2}{*}{ p Value } \\
\hline & Mean & SD & Mean & SD & & \\
\hline Strategic Thinking Skills & 4.58 & .57 & 4.56 & .53 & 0.43 & 0.67 \\
\hline Reflection & 4.68 & .78 & 4.59 & .69 & 1.21 & 0.23 \\
\hline Systems Thinking & 4.84 & .74 & 4.78 & .69 & 0.82 & 0.42 \\
\hline Reframing & 4.08 & .84 & 4.17 & .73 & -1.26 & 0.21 \\
\hline
\end{tabular}

Gender. Based on the result of the independent sample t-tests as shown in Table 5 below, the test result showed that the independent sample $t$-test was statistically insignificant $(t=.63, p>$ 0.05 ) based on the gender variable. In addition, univariate analysis based on the dimensions of strategic thinking skills by gender category can be seen in Table 4 below. It was found that there were no significant differences in the dimensions of strategic thinking skills based on gender category in the dimensions of reflection $(t=-0.90, p>0.05)$, systems thinking $(t=1.39, p>0.05)$ and reframing $(t=0.38, p>0.05)$.

Table 5. t-Test: Strategic Thinking Differences Based on Gender

\begin{tabular}{|c|c|c|c|c|c|c|}
\hline \multirow[t]{2}{*}{ Variables } & \multirow{2}{*}{$\begin{array}{l}\text { Male } \\
\text { Mean }\end{array}$} & \multirow{2}{*}{$\begin{array}{c}(n=105) \\
\text { SD }\end{array}$} & \multicolumn{2}{|c|}{ Female $(n=351)$} & \multirow[t]{2}{*}{ t Value } & \multirow[t]{2}{*}{ p Value } \\
\hline & & & Mean & SD & & \\
\hline Strategic Thinking Skills & 4.59 & 0.57 & 4.56 & 0.54 & 0.63 & 0.53 \\
\hline Reflection & 4.58 & 0.75 & 4.65 & 0.73 & -0.90 & 0.37 \\
\hline Systems Thinking & 4.89 & 0.78 & 4.78 & 0.69 & 1.39 & 0.16 \\
\hline Reframing & 4.15 & 0.79 & 4.12 & 0.78 & 0.38 & 0.71 \\
\hline
\end{tabular}

p>.05

Position. One-way ANOVA test result in Table 6 indicated that there was a significant difference in the level of strategic thinking among teachers based on position with $F$ value $(3,452)=3.396$, $p<0.05$. Tukey's post-hoc follow-up test showed that respondents holding the Senior Assistant position $(\mathrm{M}=4.9521, \mathrm{SD}=.49462)$ had higher strategic thinking skills than respondents with the post Head of Field $(M=4.6095, S D=.46087)$, Head of subject $(M=4.5790, S D=.56729)$, Secretary $(\mathrm{M}=4.5785, \mathrm{SD}=.55605)$, Regular Teacher $(\mathrm{M}=4.5287, \mathrm{SD}=.57600)$ and Class Teacher $(\mathrm{M}=$ $4.5116 \mathrm{SD}=.50521)$.

Academic Qualification. Based on the one-way ANOVA test result as shown in Table 6, the test result showed that there were significant differences in strategic thinking skills among teachers based on academic qualification, with an F value of $(3,452)=.451, p>0.05$. However, Tukey's post-hoc test did not show a significant difference based on academic qualification probably because the number of respondents was relatively small in the higher academic qualification group. 
INTERNATIONAL JOURNAL OF ACADEMIC RESEARCH IN PROGRESSIVE EDUCATION AND DEVELOPMENT

Vol. 10, No. 2, 2021, E-ISSN: 2226-6348 @ 2021 HRMARS

Table 6. One-way ANOVA Test: Strategic Thinking Differences Based on Academic Qualification

\begin{tabular}{|c|c|c|c|c|c|c|}
\hline Variables & Sources & $\begin{array}{l}\text { Sum of } \\
\text { Squares }\end{array}$ & df & $\begin{array}{l}\text { Mean } \\
\text { Square }\end{array}$ & $\mathrm{F}$ & Sig. \\
\hline \multirow[t]{3}{*}{ Position } & $\begin{array}{l}\text { Between } \\
\text { Groups }\end{array}$ & 4.978 & 5 & .996 & 3.396 & .005 \\
\hline & Within Groups & 131.911 & 450 & .293 & & \\
\hline & Total & 136.889 & 455 & & & \\
\hline \multirow[t]{3}{*}{$\begin{array}{l}\text { Teaching } \\
\text { Qualification }\end{array}$} & $\begin{array}{l}\text { Between } \\
\text { Groups }\end{array}$ & 1.786 & 3 & .595 & 1.991 & .114 \\
\hline & Within Groups & 135.103 & 452 & .299 & & \\
\hline & Total & 136.889 & 455 & & & \\
\hline \multirow[t]{3}{*}{$\begin{array}{l}\text { Academic } \\
\text { Qualification }\end{array}$} & $\begin{array}{l}\text { Between } \\
\text { Groups }\end{array}$ & 3.043 & 4 & .761 & 2.563 & .038 \\
\hline & Within Groups & 133.846 & 451 & .297 & & \\
\hline & Total & 136.889 & 455 & & & \\
\hline \multirow[t]{3}{*}{ Age } & $\begin{array}{l}\text { Between } \\
\text { Groups }\end{array}$ & .408 & 3 & .136 & .451 & .717 \\
\hline & Within Groups & 136.481 & 452 & .302 & & \\
\hline & Total & 136.889 & 455 & & & \\
\hline
\end{tabular}

\section{Discussion}

The high level of strategic thinking skills indicated that educators in mainstream schools are constantly stressing the need for the thinking approach needed to implement PPPM (2013 2025). The plan that outlined 11 strategic shifts demands sustainability of strategic approaches which is capable of translating implementation strategies into action that could improve the quality of education in schools. Indeed, this finding has proven that strategic thinking skills practiced in schools are capable of reaching and mobilizing all school citizens to work together to realize the objectives of PPPM (2013 - 2025).

The high level of strategic thinking skills is also in line with the suggestions of scholars in the field of school improvement in facing the challenges of globalization in the 21st century (Davies, 2006; Davies \& Davies, 2004; 2009; Eacott, 2008; Ronquillo, 2011). Organizational capabilities and individual characteristics demonstrated by school teachers have created strong and co-existing strategic communication and cooperation to drive school vision and mission (Davies \& Davies, 2009). Strategic leadership relationships (Kouzes \& Posner, 2003) will further lead to a review of the strategies and frameworks in progress.

In general, the differences in strategic thinking skills related to school category variables in this study can be seen in terms of the level of strategic thinking skills. The result showed that there was no significant difference in the level of strategic thinking skills among school teachers although the mean of the analysis result showed that there were differences. This may be due to the level of knowledge and exposure to higher levels and levels of knowledge that are capable of assessing and analyzing aspects more thoroughly and openly. Respondents with at least a 
bachelor's degree (more than $85 \%$ ) have been exposed to a higher level of knowledge and are more rational. The result of this study is in line with the findings of Pisapia, Pang, Hee, Lin and Morris (2009) who found no significant differences between strategic thinking skills with variables such as organizational category and respondents' location. Although there were no significant differences, the overall strategic thinking skills of the SMK teachers were found to be higher than those of the SK teachers. Rationally, these differences can be seen in the focus group aspects of teaching and learning activities in schools. SMK teachers deal with students with higher levels of cognitive ability who have different viewpoints and focus.

There were some statistically significant differences in strategic thinking skills based on the six different positions held by the respondents. Respondents who held senior assistant position (GPKs) were more likely to exhibit strategic thinking skills than other position holders in school. From a professionalism standpoint, it is important that those who may have more challenging job specifications, such as head of field and head of panitia, seemed to prefer to practice strategic thinking skills more often.. Thus, job specification in school factor indicated that teachers tend to take a strategic approach to task performance in the effort to enhance appropriate competencies.

\section{Conclusion and Suggestion}

The results of this research have answered the question of the level of strategic thinking skills of school teachers. The findings of the study showed that secondary school teachers level of strategic thinking skills were high for all the variables and all study dimensions compared to the primary school teachers. This demonstrates that the theory of strategic thinking skills is an activity that contributes to a broader concept which focuses on the future direction of the organization in order to continue operating in line with the current situation (Haycock et al., 2012). This study has also been able to identify the most commonly used dimensions of strategic thinking skills that need attention in planning direction and strategies for achieving more powerful and effective educational standards. Although there were differences for each study variable based on school category factors, statistical test showed that there was no significant difference in the level of strategic thinking skills among school teachers. The findings of this study should be considered by the stakeholders towards enhancing and developing strategic thinking skills among school teachers irrespective of the location of the school and thus strengthening school facilities to enhance the professional capacity of teachers. Therefore, it is hoped that the findings of this study can contribute to the development of high quality and credible school leaders.

In order to maximize the potential of teacher professionalism, various efforts should be made to understand which contextual aspects of the work may be most influential. Therefore, further research can be conducted taking into account other factors such as teacher self-efficacy, leadership experience, appreciation, emotional intelligence and so forth for deeper and meaningful research findings. Given that this study covered a small number of SMK and SK teachers; and involving only one state, it is proposed that future studies expand the study area as well as increase the number of schools and the number of study samples involved so that comprehensive information on strategic thinking skills among teachers can be more fully described. In addition, it is necessary that the methodology of this study be diversified to obtain 
better research results as this study has only used a quantitative method using questionnaire to obtain research data. Therefore, it is advisable that the qualitative approach such as interviews be used in future studies so that the findings are more accurate and include a broader scope.

\section{Acknowledgement}

I would like to express my sincere thanks and appreciation to the Universiti Utara Malaysia for the research grant funding, the Awang Had Salleh Graduate School and the School of Education for their support and cooperation in carrying out this study.

\section{Corresponding Author}

Mua'azam Mohamad, School of Education, Universiti Utara Malaysia, Kedah, Malaysia. E-mail: ibnu.mohamad19@gmail.com.

\section{References}

Ali, H. M. (2012). The quest for strategic Malaysian Quality National Primary School Leaders. International Journal of Educational Management, 26 (1), 83 - 98.

Atan, A. M. (2013). Beban tugas guru dalam pelaksanaan Pentaksiran Berasaskan Sekolah (PBS) di kalangan guru-guru Sekolah Kebangsaan di daerah Muar. Unpublished project reports. Universiti Teknologi Malaysia.

Barrick, M. R., \& Mount, M. K. (2005). Yes, personality matters: Moving on to more important matters. Human Performance, 18(4), 359-372.

Billingsley, B. S. (2007). Recognizing and supporting the critical roles of teachers in special education leadership. Exceptionality, 15, 163-176.

Bowring-Carr, C. (ed). School leadership in the 21st century: Developing a strategic approach. London: Routledge Falmer.

Caldwell, B. J., \& Spinks, J. M. (1988). The self managing school. London: Falmer Press.

Chan, K., \& Drasgow, F. (2001). Toward a theory of individual difference and leadership: Understanding the motivation to lead. Journal of Applied Psychology, 86, 481-498.

Davies, B. (2004). Developing the strategically focused school, School Leadership \& Management, 24(1), 11-27.

Davies, B. (2006). Leading the strategically-focused School for success and sustainability. London: Sage.

Davies, B. J., \& Davies, B. (2004). Strategic leadership, school leadership and management. Formerly School Organisation, 24(1), 29-38,

Davies, B. J., \& Davies, B. (2005). Strategic dimensions of leadership. In Davies, B., Ellison, L., \&

Eacott, S. (2006). Strategic leadership: An educational leader imperative. Perspectives on Educational Leadership, 16(6), 1-2. Retrieved from http://hdl.handle.net/1959.13/44901.

Fullan, M. (2007). The new meaning of educational change. New York: Teachers College Press. Greenwood, J. Y. (2011). African American teacher leaders: Selections, supports, barriers. Auburn University, Auburn, Alabama. Retrieved from https://etd.auburn.edu/bitstream/. 
Hamid, A. A., Ithnin, M. D., Ibrahim, K., Subrumaniam, I., \& Osman, H. (2013). Hubungan burnout dengan demografi pemimpin sekolah di Malaysia. Proceeding of Nasional Pengurusan dan Kepimpinan Pendidikan Kali ke-20 on 2-4 Julai 2013.

Haycock, K., Cheadle, A., \& Bluestone, K. S. (2012). Strategic thinking. Library Leadership \& Management, 26(3), 1-23.

Heracleous, L. (1998). Strategic thinking or strategic planning. Long Range Planning, 31(3), 481487.

Jamalizadeh, Z., Jamalizadeh, G., Ahmadi, S. A. A., \& Amini, M. T. (2013). Assessment of strategic thinking in The Islamic Republic Of Iran, Hormozgan University Of Medical Sciences Based On Jane Liedtka Model. Journal of American Science, 9(2s), 113-117.

Jelenc, L., \& Pisapia, J. (2015). Individual entrepreneurial behavior in Croatian IT firms: The contribution of strategic thinking skills. Journal of Information and Organizational Sciences, 39(2), 163-182.

Katzenmeyer, M., \& Moller, G. (2009). Awakening the sleeping giant: Helping teacher develop as leaders (3rd ed.). CA: Corwin.

Kementerian Pelajaran Malaysia. (2012). Laporan awal pelan pembangunan pendidikan Malaysia 2013-2025. Putrajaya; Kementerian Pendidikan Malaysia.

Kementerian Pendidikan Malaysia. (2013). Pelan Pembangunan Pendidikan Malaysia 2013 2025. Putrajaya; Kementerian Pendidikan Malaysia.

Kho, F. C. Y., Yusof, H., \& Mohamad, S. Y. S. (2016). Development and validation of the teacher leadership competency scale. Malaysian Journal of Learning and Instruction, 13(2), 4369.

Kowalski, T. J. (2010). The school principal: Visionary leadership and competent management. NewYork \& London: Routledge Taylor \& Francis Group.

Mintzberg, H. (2000). The rise and fall of strategy planning. The Academy of Management Review, $72(1)$.

Pisapia, J., Ellington, L., Toussaint, G., \& Morris, J.D. (2011). Strategic thinking skills: Validation and confirmation of constructs. http://fau.academia.edu/JohnPisapia/.

Pisapia, J., Pang, N.S-K., Hee, T. F., Lin, Y., \& Morris, J. D. (2009). A comparison of the use of strategic thinking skills of aspiring school leaders in Hong Kong, Malaysia, Shanghai, and the United States: An exploratory study. International Education Studies, 2(2), 46-58.

Pisapia, J., Reyes-Guerra, D., \& Coukos-Semmel, E. (2005). Leadership Review, 5, 41-68.

Sekaran, U., \& Bougie, R. (2010). Research methods for business: A skill-building approach (5th ed). New York: John Wiley \& Sons Ltd.

Sekaran, U. (2014). Research methods for business: A skill-building approach. Singapore: John Willey \& Sons.

Sihes, A. J., \& Shaari, M. Z. (2010). Kepuasan kerja di kalangan guru teknikal di empat buah sekolah menengah teknik sekitar Johor Bahru. Unpublished paperwork, Institutional Repository, Universiti Teknologi Malaysia.

Weyhrauch, W. S. (2016). A mindset for strategic thinking developing a concept and measure. Kansas State University. Manhattan: Kansas.

Yukl, G. (2013). Leadership in organization. New Jersey: Prentice Hall

Zaccaro, S. J. (2007). Trait-based perspectives of leadership. American Psychologist, 62(1), 6-16. 